\title{
Do reconhecimento da ocupação de naturólogo pela classificação brasileira de ocupações (CBO) à regulamentação da profissão pelo Congresso Nacional: conquistas, demandas e estratégias políticas
}

\section{The recognition of the occupation of naturologist by the Brazilian Classification of Occupations (CBO) for regulating the profession in the Brazilian Congress: achievements, demands and political strategies}

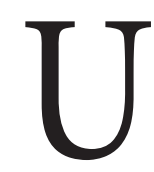

niversidade do Sul de Santa Catarina, em um investimento pioneiro, em 1998, criou o primeiro bacharelado de Naturologia, no Brasil. Mais tarde, a Universidade Anhembi Morumbi, em 2002, no estado de São Paulo, também implantou o curso de graduação. Atualmente, ambos os cursos são reconhecidos pelo MEC e avaliados com 5 estrelas pelo Guia do Estudante da Editora Abril.

Em 17 anos de existência, a Naturologia, no Brasil, já se faz presente em diversos campos de atuação. SPA's, Hospitais, Clínicas Multiprofissionais, Hotéis, Policlínicas e também no setor público por meio do Sistema Único de Saúde (SUS) já podem usufruir do desempenho profissional de cerca de dois mil naturólogos, dentre os quais há, também, aqueles que seguem a carreira acadêmica, fazendo mestrado e doutorado, e dedicando-se ao ensino e à pesquisa.

Recentemente, a ocupação de Naturólogo foi reconhecida pelo Ministério do Trabalho, com a sua inclusão na Classificação Brasileira de Ocupações (CBO), cujo registro é representado pela numeração 2263-20. Além do Naturólogo, outras 13 ocupações foram incluídas em 2015.

Esse registro na Classificação Brasileira de Ocupações (CBO) trata do reconhecimento da existência de ocupações no mercado de trabalho, no país. E, para a Naturologia, significa relevante conquista em favor da consolidação da profissão, além de sinalizar o amparo e a valorização que, provenientes do governo, implicam inclusão social, favorecendo-lhe relações contratuais pelo setor público e privado, regulamentando as condições para a criação de concursos públicos para o Naturólogo. Resultam, daí, maior visibilidade e credibilidade à categoria profissional.

Afinal, a partir da CBO, desdobram-se outras legislações que poderão contemplar a existência da profissão de Naturólogo e, consequentemente, assegurar-lhe o devido amparo requisitado em relações trabalhistas: Relação Anual de Informações Sociais (RAIS); Cadastro Geral de Empregados e Desempregados (CAGED); Seguro Desemprego; Preenchimento Carteira de Trabalho; Qualificação Profissional; Aprendizagem; Intermediação de mão-de-obra; Imigração; Fiscalização do trabalho; Ministério da Saúde - registros de: mortalidade profissional, incidência de doenças relacionadas à ocupação e Rede Interagencial de Informações para a Saúde (RIPSA); Imposto de Renda Pessoa Física; Previdência Social - CNIS (Cadastro Nacional de Informações Sociais); IBGE - Pesquisas: Censo, Pesquisa Nacional de Amostra por Domicílios (PNAD), Pesquisa Mensal de Emprego (PME) (BRASIL, 2015).

Outra das demandas pertinentes à consolidação da profissão no Brasil, refere-se à regulamentação da profissão. O Projeto de Lei (PL) 3804/2012 que regulamenta o profissional está em trâmite no Congresso Nacional. Atualmente o PL encontra-se na Comissão de Educação (CE) da Câmara dos Deputados, tendo como relatora a deputada Alice Portugal, do Partido Comunista do Brasil (PCdoB).

Anteriormente, o projeto estava na Comissão de Seguridade Social e Família (CSSF). Enquanto tramitou nessa comissão que avalia o mérito de projetos de lei, o PL ganhou força, aliados e visibilidade por intermédio de debates em audiências públicas e diálogos com os deputados. Cabe ressaltar a luta incansável das 
associações que representam a classe de naturólogos, em prol da consolidação da profissão, quais sejam a Sociedade Brasileira de Naturologia (SBNAT), Associação Brasileira de Naturologia (ABRANA) e Associação Paulista de Naturologia (APANAT).

Devido a alguns fatores relativos a estratégias adotadas pelos representantes políticos nos órgãos governamentais, o projeto foi transferido da Comissão de Seguridade Social e Família (CSSF) para a Comissão de Educação (CE). Os rumos das tramitações do Projeto de Lei estão, pois, sujeitos a pressões corporativistas sofridas pelo setores encarregados das avaliações específicas das diligências. Exemplo disso é o perfil da atuação do Departamento de Gestão e da Regulação do Trabalho em Saúde (DEGERTS) do Ministério da Saúde. Trata-se de departamento que já possui um histórico de oposição à regulamentação de profissões que, ainda que relacionadas à área da saúde, não fazem parte daquelas consideradas hegemônicas. Esse corporativismo exercido por lideranças bem articuladas politicamente vem orquestrando a ascendência sobre o poder de decisão de parlamentares e desses departamentos, alterando, muitas vezes, o destino das expectativas de novas profissões.

$\mathrm{O}$ argumento mais utilizado, para fundamentar à regulamentação de novas profissões na área da saúde, assenta-se no convencimento infundado de que elas não possuem escopo de práticas exclusivo e são especialidades de outras profissões já regulamentadas. No que concerne à Naturologia e seus profissionais, as associações representativas já demonstraram o equívoco, contrapondo-se a esses argumentos mediante esclarecimentos fundamentados em pesquisas e estudos comparativos, bem como apresentando-se inteiramente à disposição do diálogo entre as entidades representativas da Naturologia, das Práticas Integrativas e Complementares (PIC's) e do Ministério da Saúde.

\section{REFERÊNCIAS}

1. Brasil. Ministério do Trabalho. Classificação Brasileira de Ocupações. 2015.
Quando o projeto estava na Comissão de Seguridade Social e Família (CSSF), o relator do PL foi o Deputado Luiz Henrique Mandetta do Democratas (DEM) do Mato Grosso do Sul, que é médico, ortopedista infantil, com larga experiência em gestão pública na saúde coletiva. O deputado Mandetta apresentou um substitutivo do PL original e também um relatório favorável à regulamentação da profissão do Naturólogo.

Assim prosseguem as diligências para a regulamentação da profissão do Naturólogo pelo Congresso Nacional.

É imprescindível, todavia, a união dos profissionais, estudantes e militantes da causa para dar andamento à administração e à execução de ações efetivas de marketing favorável à ampliação da visibilidade da profissão, demonstrando a relevância social e o interesse público pela Naturologia.

É nesse contexto que também se incluem os objetivos de criação e implantação de cursos superiores de bacharelado de Naturologia nas diferentes regiões do país e por instituições públicas. Já, no âmbito acadêmico, urge ampliar a publicação de estudos sobre os referenciais teóricos próprios da Naturologia, estudos de custo-efetividade das práticas naturológicas; estudos de possíveis riscos da utilização de práticas naturológicas por profissionais não capacitados e estudos que abordem a relevância social e o interesse público.

A Naturologia, a serviço do cuidado humano e comprometida com a inserção da profissão na sociedade, por meio de seus atores, está dinamicamente envolvida com esse panorama, ora apresentado, em que todas as ações confluem para o aval solidário do lugar e da responsabilidade do Naturólogo no diálogo com todas as demais práticas de atenção à saúde, de pesquisa e de estudo.

\section{Daniel Maurício de Oliveira Rodrigues}

Editor-chefe 